\title{
Extraction and characterization of cellulose microfibers from Retama raetam stems
}

\author{
Abdelkader Khenblouche ${ }^{1 *}$ (D), Djamel Bechki ${ }^{1}$, Messaoud Gouamid², Khaled Charradi ${ }^{3}$ Ladjel Segni ${ }^{4}$, \\ Mohamed Hadjadj 5 and Slimane Boughali ${ }^{1}$
}

\author{
${ }^{1}$ Laboratory of New and Renewable Energy in Arid Zones - LENREZA, University of Ouargla, \\ Ouargla, Algeria \\ ${ }^{2}$ Department of Chemistry, Faculty of Mathematics \& Material Sciences, University of Ouargla, \\ Ouargla, Algeria \\ ${ }^{3}$ Laboratory of Nanomaterials and Systems for Renewable Energies - LaNSER, Research and Technology \\ Center of Energy, Techno-park Borj-Cedria, Hammam-Lif, Tunis, Tunisia \\ ${ }^{4}$ Laboratory of Process Engineering, Faculty of Applied Sciences, University of Ouargla, Ouargla, Algeria \\ ${ }^{5}$ Laboratory of Valorization and Promotion of Saharian Resources - VPRS, University of Ouargla, \\ Ouargla, Algeria \\ *khenblouche89@gmail.com
}

\begin{abstract}
Cellulose is the most abundant renewable resource in nature, it has various industrial applications due to its promising properties. Retama raetam is a wild plant belonging to the Fabaceae family, largely abundant in arid area which makes it a good candidate for industrial utilization. In the present study, highly crystalline cellulose microfibers $(77.8 \% \mathrm{CrI})$ were extracted from Retama Raetam stems as a novel renewable source. The samples underwent a dewaxing process, then the microfibers were extracted using $7 \mathrm{wt} \%$ sodium hydroxide followed by a bleaching treatment. The extracted cellulose microfibers were characterized by Scanning electron microscopy, Fourier transform infrared spectroscopy, X-ray Diffraction and thermo-gravimetric analysis.
\end{abstract}

Keywords: cellulose, microfibers, Retama raetam, extraction, characterization.

How to cite: Khenblouche, A., Bechki, D., Gouamid, M., Charradi, K., Segni, L., Hadjadj, M., \& Boughali, S. (2019). Extraction and characterization of cellulose microfibers from Retama raetam stems. Polímeros: Ciência e Tecnologia, 29(1), e2019011. https://doi.org/10.1590/0104-1428.05218

\section{Introduction}

Over the last few decades, The use of natural fibers instead of synthetic fibers as reinforcement materials for polymer composites has gained considerable attention because of their unique characteristics, such as renewability, biodegradability, processing flexibility, low density, high specific strength and low-cost ${ }^{[1,2]}$. In addition, natural fibers have applications in various fields such as bioenergy industries, automobiles, paper manufacturing and textile owing to their properties and broad availability ${ }^{[1,3]}$. As a result, nowadays, the subject of many researchers worldwide focuses on the need to find alternative fiber sources ${ }^{[4]}$. Among all natural fibers, cellulose has attracted much interest as it is the most abundant renewable resource in nature and the degradation of cellulosic biomass is an important part of the biosphere's carbon cycle ${ }^{[5]}$. Its existence as the common material of plant cell walls was first investigated by Braconnot in $1819^{[6]}$ and Payen in $1838^{[7]}$. It is a polydispersed linear polymer with a microfibrillar structure composed of poly-b $(1 \rightarrow 4)$-D-glucose units with a syndiotactic configuration ${ }^{[8,9]}$, found in the cell walls as a network of microfibrils embedded in a non-cellulosic matrix ${ }^{[10]}$. Several plants are rich in cellulose, i.e. cotton, wood, bamboo, hemp, flax, and jute ...etc ${ }^{[11]}$. In addition, cellulose fibers have been extracted from several sources such as; milkweed stems ${ }^{[12]}$, hop stems ${ }^{[13]}$, rice husk ${ }^{[14]}$, Cissus quadrangularis root ${ }^{[15]}$, dichrostachys cinerea bark ${ }^{[1]}$ and many more. Although several sources of natural fibers were investigated in detail, the isolation of cellulose fibers from R. Raetam has not been reported yet.

Retama raetam, locally known as R'tem, is a wild plant of the Fabaceae family. It is common to North and East Mediterranean regions ${ }^{[16]}$. It is largely abundant in arid area; this abundance makes it a good candidate for industrial utilization. Moreover, the Retama species contributes to the bio-fertilization of poor grounds because of their aptitude to associate with fixing nitrogen bacteria Rhizobia ${ }^{[17]}$. Therefore, the genus of the Retama is included in a re-vegetation program for degraded areas in semi-arid Mediterranean environments ${ }^{[18]}$.

In this research, Natural micro-sized cellulose fibers were extracted from R. Raetam stems using alkali and bleaching treatments, the resultant cellulose microfibers were characterized using FTIR, SEM, XRD and TGA. 


\section{Materials and Methods}

\subsection{Materials}

Stems of R. raetam subject of this study were collected in Ouargla, Algeria, in 2015. Acetone, Ethanol, Sodium hydroxide \& Hydrogen peroxide were purchased from Sigma-Aldrich and were used without further purification.

\subsection{Preparation of samples}

Adult stems were cleaned with water and air dried, broken to the size of about $1 \mathrm{~cm}$ long and $1 \mathrm{~mm}$ width, grinded into powder with a Retsch SM100 Comfort cutting mill (Retsch GmbH, Haan, Germany), and sieved using a sieve size of $0.25 \mathrm{~mm}$.

\subsection{Microfibers extraction}

The extraction of cellulose microfibers was performed using classical chemical treatments with adaptations in dewaxing, alkali and bleaching treatment processes. The totally chlorine-free extraction procedure can be described as follows:

\subsubsection{Dewaxing}

About 20g of powdered stems were first dewaxed in a Soxhlet reflux with a 2:1 (v/v) mixture of Acetone/Ethanol at $63{ }^{\circ} \mathrm{C}$ for $7 \mathrm{~h}$, the main purpose of this step is to remove off waxes and extractives, the sample was then placed in a Buckner funnel and vacuum dried at room temperature for $3 \mathrm{~h}$ to remove traces of residual solvents.

\subsubsection{Alkali treatment}

The alkali treatment was performed to purify the cellulose by removing lignin and hemicellulose from $\mathrm{R}$. Raetam fibers. The extractive-free sample was treated with an alkali solution (7 wt $\% \mathrm{NaOH}$ ) with a solvent to solid ratio of 10:1 at 80 ${ }^{\circ} \mathrm{C}$ for $3 \mathrm{~h}$ under mechanical stirring. This treatment was performed trice, after each treatment the solid was filtered and washed with distilled water until neutral $\mathrm{pH}$.

\subsubsection{Bleaching}

A subsequent bleaching treatment was carried out to remove residual lignin and whiten the microfibers. The sample was immersed in a hydrogen peroxide solution $(11 \%$, $\mathrm{v} / \mathrm{v}$ ), the $\mathrm{pH}$ was adjusted to 11 using $7 \mathrm{wt} \% \mathrm{NaOH}$, the system was vigorously stirred for $3 \mathrm{~h}$ at $45^{\circ} \mathrm{C}$. For a more effective discoloration, the bleaching process was performed twice under the same conditions, after each treatment, the microfibers were filtered and washed with distilled water.

\subsection{Fourier transform infrared spectroscopy}

To analyze the chemical changes of the samples and investigate functional groups in the extracted cellulose we used Fourier Transmission Infra-Red Spectroscopy. The FTIR spectra were recorded on a Cary 660 FTIR Spectrometer (Agilent Technologies, USA) in a wavelength range of $4000-600 \mathrm{~cm}^{-1}$ with a resolution of $4 \mathrm{~cm}^{-1}$.

\subsection{X-ray Diffraction (XRD) analysis}

The crystallinity of cellulose microfibers was investigated by X-ray diffraction (XRD) analysis, using a powder X-ray diffractometer (D8 Advance A25 Bruker AXS GbmH., Germany) with $\mathrm{Cu} \mathrm{K} \alpha$ radiation $\left(1.5406 \mathrm{~A}^{\circ}\right)$ at $40 \mathrm{kV}$ and $25 \mathrm{~mA}$, in the range of $2 \theta=5-60^{\circ}$ at a scanning rate of $0.02^{\circ}$ $\mathrm{s}^{-1}$. The crystallinity index $(\mathrm{CrI})$ was calculated according to Segal equation ${ }^{[19]}$ :

$$
C r I=100 \times\left(I_{200}-I_{a m}\right) / I_{200}
$$

where $I_{200}$ is the diffraction intensity at $2 \theta=22-23^{\circ}$; and $I_{A M}$ is the minimum diffraction intensity at $2 \theta=18-20^{\circ}$.

The crystallite size was calculated as per the Scherrer equation $^{[20]}$

$$
L_{h, k, l}=(0.94 \times \lambda) /(\beta \times \cos \theta)
$$

where $\lambda$ is $X$-rays wavelength; $\beta$ is the full width at half maximum in radians; and $\theta$ is the Bragg angle.

\subsection{Morphological structure}

A scanning electron microscope (SEM) (Quanta 250 FEG, FEI, USA) with an accelerating voltage of $15 \mathrm{kV}$ was used to investigate the microstructure and the surface morphology of the obtained cellulose microfibers.

\subsection{Thermogravimetric Analysis (TGA)}

In order to study the thermal stability of the extracted cellulose microfibers, thermogravimetric analysis (TGA) was performed using a Mettler Toledo TGA/DSC 3+ instrument. The scan was carried out from 25 to $600{ }^{\circ} \mathrm{C}$ at a heating rate of $10^{\circ} \mathrm{C} / \mathrm{min}$ and under nitrogen atmosphere.

\section{Results and Discussion}

\subsection{Extraction method and cellulose yield}

A stepwise totally chlorine-free procedure for the isolation of cellulose microfibers from retama raetam was proposed in this paper based on that adopted by Sun et al. ${ }^{[21]}$

\begin{tabular}{|c|c|c|}
\hline Source & Crystallinity index (CrI) & Reference \\
\hline Coconut palm leaf sheath & $47.7 \%$ & Uma Maheswari et al. ${ }^{[22]}$ \\
\hline Sugarcane bagasse & $50 \%$ & Jonjankiat et al. ${ }^{[23]}$ \\
\hline Agave fibers & $64.4 \%$ & Reddy et al. ${ }^{[24]}$ \\
\hline Mengkuang leaves & $69.5 \%$ & Sheltami et al. ${ }^{[3]}$ \\
\hline Soy hulls & $69.6 \%$ & Alemdar and Sain ${ }^{[25]}$ \\
\hline Commercial microcrystalline cellulose & $73.91 \%$ & Kale et al. ${ }^{[20]}$ \\
\hline Sisal fibers & $75 \% \pm 1$ & Morán et al. ${ }^{[26]}$ \\
\hline Wheat straw & $77.8 \%$ & Alemdar and Sain ${ }^{[25]}$ \\
\hline Retama Reatam & $77.8 \%$ & This work \\
\hline Hibiscus sabdariffa & $78.95 \%$ & Sonia and Priya Dasan ${ }^{[27]}$ \\
\hline Palmyra palm Fruits & $81.9 \%$ & Reddy et al. ${ }^{[28]}$ \\
\hline
\end{tabular}

Table 1. Comparison of the crystallinity index of cellulose microfibers from various sources. 
with modifications. These modifications involve increasing sodium hydroxide and hydrogen peroxide concentrations as well as improving treatment time and/or temperature to enhance non-cellulosic components removal. Therefore, the isolation of R. Raetam cellulose microfibers was successfully achieved without any additional harsh acid treatments (Table 1), which makes the suggested extraction process not only eco-friendly and cost-saving, but also yielding cellulose microfibers of higher crystallinity and smaller diameters as further confirmed by XRD and SEM results.

Cellulose microfibers yield was gravimetrically determined (calculated as the percentage of the extracted cellulose microfibers over the initial raw sample weight) and was found to be $52.1 \%$. This yield value is higher than that reported in literature for cellulose microfibers extracted from Hibiscus sabdariffa fibers $(38.6 \%)^{[27]}$ and comparable to yield values of 52,52 and $55 \%$ for cellulose microfibers extracted from Coconut palm leaf sheath ${ }^{[22]}$, African Napier grass $^{[29]}$ and Palmyra palm fruits ${ }^{[28]}$, respectively.

\subsection{FT-IR spectroscopic analysis}

Infrared spectroscopy is currently one of the most important analytical techniques available to scientists ${ }^{[30]}$. It presents a relatively easy method of obtaining direct information on chemical changes that occur during chemical treatments ${ }^{[31]}$. Furthermore, FT-IR analysis was conducted to investigate the presence of different functional groups in the isolated samples. Figure 1. shows the IR spectra of (a) untreated sample, (b) alkali treated sample and (c) bleached cellulose microfibers. As summarized in Table 2,

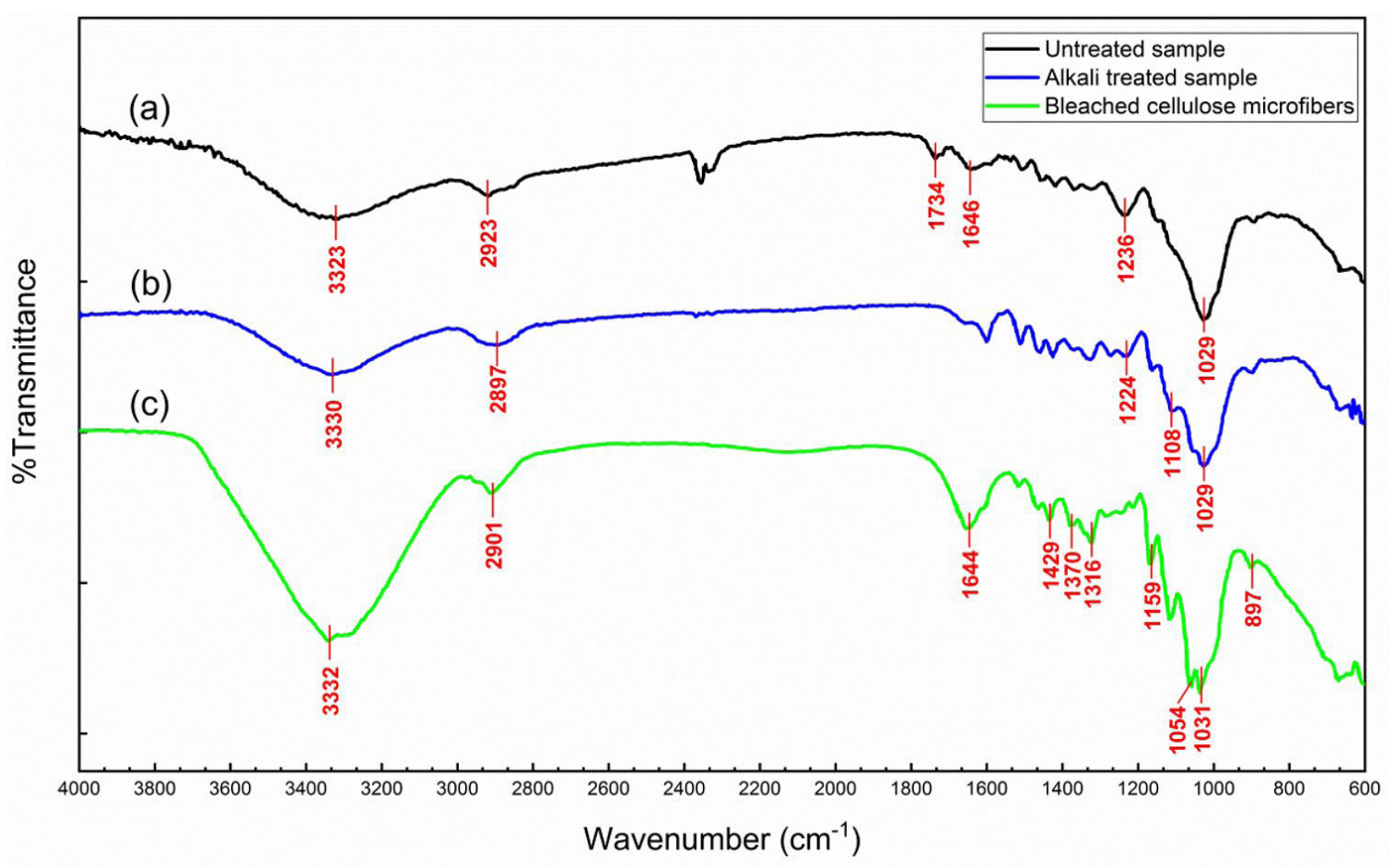

Figure 1. FT-IR spectra of (a) untreated sample, (b) alkali treated sample and (c) bleached cellulose microfibers.

Table 2. The main observed IR bands and their assignments.

\begin{tabular}{|c|c|c|c|}
\hline Spectra & Wavenumber $\left(\mathrm{cm}^{-1}\right)$ & Assignment & Ref. \\
\hline (a), (b), (c) & $876-897$ & 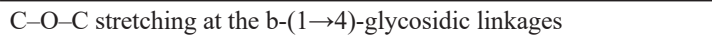 & Oh et al. ${ }^{[32]}$ \\
\hline (a), (b), (c) & $1029-1031$ & $\mathrm{C}-\mathrm{O}-\mathrm{C}$ pyranose ring skeletal vibration & Sun et al..$^{[33]}$ \\
\hline (b), (c) & $1051-1054$ & $\mathrm{C}-\mathrm{O}-\mathrm{C}$ pyranose ring skeletal vibration & Sun et al..$^{[33]}$ \\
\hline (a), (b), (c) & $1144-1159$ & 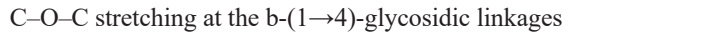 & Oh et al. ${ }^{[32]}$ \\
\hline (a), (b) & $1224-1236$ & $-\mathrm{COO}$ vibration of acetyl groups / $\mathrm{C}-\mathrm{O}$ stretching of the aryl group & Reddy et al. ${ }^{[28]}$ \\
\hline (a), (b), (c) & $1316-1327$ & $\mathrm{C}-\mathrm{C}$ and $\mathrm{C}-\mathrm{O}$ skeletal vibrations & Gao et al. ${ }^{[34]}$ \\
\hline (a), (b), (c) & $1370-1374$ & $\mathrm{O}-\mathrm{H}$ bending & Gao et al. ${ }^{[34]}$ \\
\hline (a), (b), (c) & $1417-1429$ & $\mathrm{CH} 2$ bending & Gao et al. ${ }^{[34]}$ \\
\hline (a), (b), (c) & $1644-1646$ & $\mathrm{OH}$ bending of the absorbed water & Alemdar and Sain ${ }^{[25]}$ \\
\hline (a) & 1734 & $\mathrm{C}=\mathrm{O}$ stretching & Sain and Panthapulakkal ${ }^{[35]}$ \\
\hline (a), (b), (c) & $2896-2922$ & $\mathrm{C}-\mathrm{H}$ stretching & Kondo and Sawatari ${ }^{[36]}$ \\
\hline (a), (b), (c) & $3323-3332$ & H-bonded $\mathrm{OH}$ groups stretching & Kondo and Sawatari ${ }^{[36]}$ \\
\hline
\end{tabular}


the cellulose spectrum is similar to those reported in literature for cellulose fibers ${ }^{[37]}$.

The band at $3332 \mathrm{~cm}^{-1}$ relates to the stretching of $\mathrm{H}$-bonded $\mathrm{OH}$ groups, and the one at $2901 \mathrm{~cm}^{-1}$ to the $\mathrm{C}-\mathrm{H}$ stretching ${ }^{[36]}$, we observe that the band around $3332 \mathrm{~cm}^{-1}$ is narrower and has a higher intensity for cellulose, which demonstrated that the extracted cellulose contained more-OH groups than in untreated sample ${ }^{[10]}$. The band at $1644 \mathrm{~cm}^{-1}$ is associated with $-\mathrm{OH}$ bending of the absorbed water ${ }^{[25]}$. Typical bands assigned to cellulose at $1159 \mathrm{~cm}^{-1}$ and $897 \mathrm{~cm}^{-1}$ are due to $\mathrm{C}-\mathrm{O}-\mathrm{C}$ stretching at the b- $(1 \rightarrow 4)$-glycosidic linkages ${ }^{[32]}$. The presence of these peaks showed the increase in the percentage of cellulosic components after the removal of non-cellulosic materials by chemical treatments ${ }^{[38]}$. The absorption peak at $\sim 1734 \mathrm{~cm}^{-1}$ on the spectrum of the untreated sample (a) is attributed to the $\mathrm{C}=\mathrm{O}$ stretching of the acetyl and uronic ester groups of polysaccharides ${ }^{[9,35]}$, it is also related to the p-coumeric acids of lignin and/or hemicellulose ${ }^{[25]}$, the absence of this peak after successive chemical treatments indicates the removal of most of lignin and hemicelluloses from the microfibers. Another indicator of lignin and hemicellulose removal during the chemical treatments is the significant decrease in the intensity of the peak around $1236 \mathrm{~cm}^{-1}$ which is related to the $-\mathrm{COO}$ vibration of acetyl groups in hemicellulose and/or the $\mathrm{C}-\mathrm{O}$ stretching of the aryl group in lignin ${ }^{[28]}$. Noticeable peaks on spectrum (c) at $1429 \mathrm{~cm}^{-1}$ relates to the $\mathrm{CH}_{2}$ bending and at $1370 \mathrm{~cm}^{-1}$ to the $\mathrm{O}-\mathrm{H}$ bending. The absorbance at $\sim 1316 \mathrm{~cm}^{-1}$ is attributed to the $\mathrm{C}-\mathrm{C}$ and $\mathrm{C}-\mathrm{O}$ skeletal vibrations $^{[34]}$. The $\mathrm{C}-\mathrm{O}-\mathrm{C}$ pyranose ring skeletal vibration occurs in $1054 \mathrm{~cm}^{-1}$ and $1031 \mathrm{~cm}^{-1[33]}$.

\subsection{X-ray Diffraction measurements}

Figure 2 exhibits the XRD data of the extracted cellulose microfibers. The cellulose amorphous phase is characterized by the low diffracted intensity at a $2 \theta$ value of $19.12^{\circ}$, whilst the peaks at $15.14^{\circ}, 16.25^{\circ}, 22.75^{\circ}$ and $34.39^{\circ}$ are attributable to the crystallographic planes of (1-10), (110), (200) and (004), respectively, which are characteristic of the typical cellulose I structure ${ }^{[29,39]}$. The crystallinity index $(\mathrm{CrI})$ of the bleached microfibers was determined using Segal equation and was found to be $77.8 \%$. Obviously, as illustrated in Table 1, this CrI value is higher than the value of $73.91 \%$ reported by Kale et al. for commercial microcrystalline cellulose from wood pulp ${ }^{[20]}$. Moreover, it is higher than the $\mathrm{CrI}$ values reported in the literature for cellulose microfibers isolated using different methods from various sources such as Sugarcane bagasse $(50 \%)^{[23]}$, Agave fibers $(64.4 \%)^{[24]}$, mengkuang leaves $(69.5 \%)^{[3]}$ and Soy hulls $(69.6 \%)^{[25]}$.

Furthermore, the crystallite size $\left(\mathrm{L}_{\mathrm{h}, \mathrm{k}, \mathrm{l}}\right)$ which was found to be $3.62 \mathrm{~nm}$ is comparable to the reported sizes of cellulose crystallites ( 4 to $7 \mathrm{~nm}$ generally) ${ }^{[40]}$. However, the calculated $\mathrm{L}_{\mathrm{h}, \mathrm{k}, \mathrm{l}}$ value is much lower than that reported for hydrolyzed commercial microcrystalline cellulose (10.32 nm). The higher CrI and the lower $\mathrm{L}_{\mathrm{h}, \mathrm{k}, \mathrm{l}}$ values suggest that the adopted stepwise chlorine-free extraction treatments were effective in removing most of amorphous domains leading to break the bundles of cellulose fibers to form smaller cellulose crystallites ${ }^{[41,42]}$.

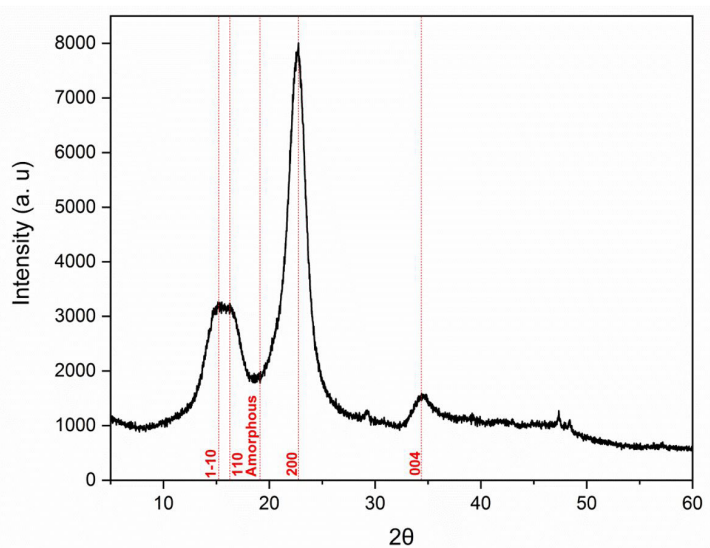

Figure 2. XRD diffractogram of the extracted R. Raetam cellulose microfibers.

\subsection{Morphological properties of chemically purified cellulose microfibers}

Figure 3 shows SEM micrographs of the chemical-purified cellulose microfibers. After they had been subjected to alkaline solution treatment and bleaching, the cellulose microfibers were separated into individual micro-sized fibers. These micro-sized cellulose fibers were reported to be composed of strong hydrogen bonding nanofibers ${ }^{[43]}$. The diameter of the microfibers is about 6-7 $\mu \mathrm{m}$ but the exact determination of their length is difficult.

As Table 3. demonstrates, the extracted R. Raetam cellulose microfibers are smaller in diameter as compared to those isolated by different extraction methods from various sources such as sisal fibers, agave fibers, coconut palm leaf sheath, soy hull and wheat straw ${ }^{[22,24-26]}$. Moreover, they are comparable to cotton and sugarcane bagasse microfibers extracted by sulfuric and nitric acid hydrolysis, respectively ${ }^{[23,44]}$. This morphology and smaller diameter would enable R. Raetam cellulose microfibers to be used for various applications ranging from reinforcing agents in biodegradable composites, to gel forming food and cosmetic additives $^{[24,45]}$

\subsection{Thermal stability}

Investigating thermal properties of cellulose microfibers is a key factor for their applicability as reinforcing fillers in biocomposites ${ }^{[38]}$. Figure $4 \mathrm{a}$ and $4 \mathrm{~b}$ shows, respectively, the thermogravimetric analysis (TGA), and the derivative thermogram (DTG) curves for both the raw and bleached samples. TGA curves show an initial weight loss below $155^{\circ} \mathrm{C}$, this initial drop $(4.6 \%$ for raw sample and $6.5 \%$ for cellulose microfibers) was due to the evaporation of moisture bounded on the surface of the samples, chemisorbed water bounded inside the samples and/or the compounds of low molecular weight such as extractives presented in the raw sample $\mathrm{e}^{[38,46]}$, the presence of the absorbed water was affirmed previously through the FT-IR results. The main broader cellulose thermal degradation $(50.84 \%)$ occurs over $179^{\circ} \mathrm{C}$ and involves synchronous multi-processes such as dehydration, depolymerization and decomposition 
Table 3. Comparison of the diameters of cellulose microfibers extracted from various sources by different extraction methods.

\begin{tabular}{|c|c|c|c|}
\hline Source & Extraction method & diameter $(\mu \mathrm{m})$ & Ref. \\
\hline Sisal fibers & Alkali, peroxide and $\mathrm{HNO}_{3} / \mathrm{HAc}$ treatments & $12.8-31$ & Morán et al. ${ }^{[26]}$ \\
\hline Coconut palm leaf sheath & Chlorination, alkali and $\mathrm{HNO}_{3} / \mathrm{HAc}$ treatments & $10-15$ & Uma Maheswari et al. ${ }^{[22]}$ \\
\hline Soy hull & Alkali treatment and $\mathrm{HCl}$ Acid hydrolysis & $10-15$ & Alemdar and Sain ${ }^{[25]}$ \\
\hline Wheat straw & Alkali treatment and $\mathrm{HCl}$ Acid hydrolysis & $10-15$ & Alemdar and Sain ${ }^{[25]}$ \\
\hline Agave fibers & Chlorination, alkali and $\mathrm{HNO}_{3} / \mathrm{HAc}$ treatments & $8-14$ & Reddy et al. ${ }^{[24]}$ \\
\hline Hibiscus sabdariffa & Steam explosion and oxalic acid hydrolysis & 10.04 & Sonia and Priya Dasan ${ }^{[27]}$ \\
\hline Sisal fibers & Chlorination and alkali treatments & $7-11.2$ & Morán et al. ${ }^{[26]}$ \\
\hline Cotton & Sulfuric acid hydrolysis & $5-10$ & Chatterjee et al. ${ }^{[4]]}$ \\
\hline Sugarcane bagasse & Nitric acid hydrolysis & $5-10$ & Jonjankiat et al. ${ }^{[23]}$ \\
\hline Palmyra palm fruit & Chlorination, alkali and $\mathrm{HNO}_{3} / \mathrm{HAc}$ treatments & $4-11$ & Reddy et al..$^{[28]}$ \\
\hline Napier grass fibers & Chlorination, alkali and $\mathrm{HNO}_{3} / \mathrm{HAc}$ treatments & 8.3 & Reddy et al. ${ }^{[29]}$ \\
\hline Retama Raetam Stems & Alkali and alkaline peroxide treatments & $6-7$ & This work \\
\hline Jatropha Curcus L seed shell & Chlorination, alkali and $\mathrm{HNO}_{3} / \mathrm{HAc}$ treatments & $0.23-1.04$ & Puttaswamy et al. ${ }^{[45]}$ \\
\hline
\end{tabular}

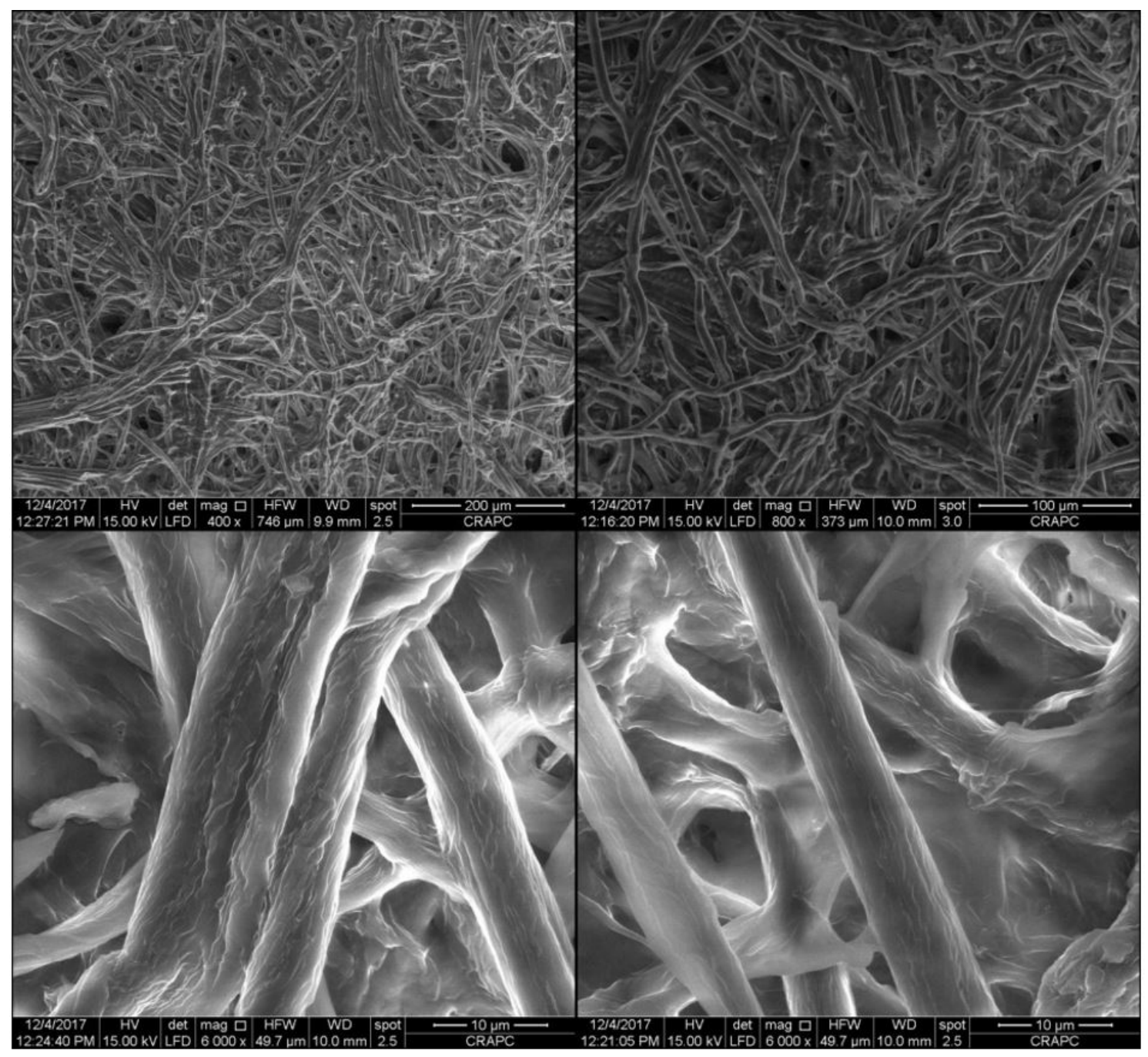

Figure 3. SEM images of the extracted R. Raetam cellulose microfibers.

of glycosidic units ${ }^{[47]}$. The raw sample showed separated pyrolysis processes within a wider temperature range, including thermal depolymerization of hemicellulose up to $273{ }^{\circ} \mathrm{C}$, decomposition of cellulose up to $348^{\circ} \mathrm{C}$, and the degradation of lignin up to $536{ }^{\circ} \mathrm{C}$ in addition to its simultaneous decomposition with other degradation stages due to its complex structure ${ }^{[46]}$. DTG curves exhibited maximum decomposition rates at $\mathrm{DTG}_{\max }=294{ }^{\circ} \mathrm{C}$ and 

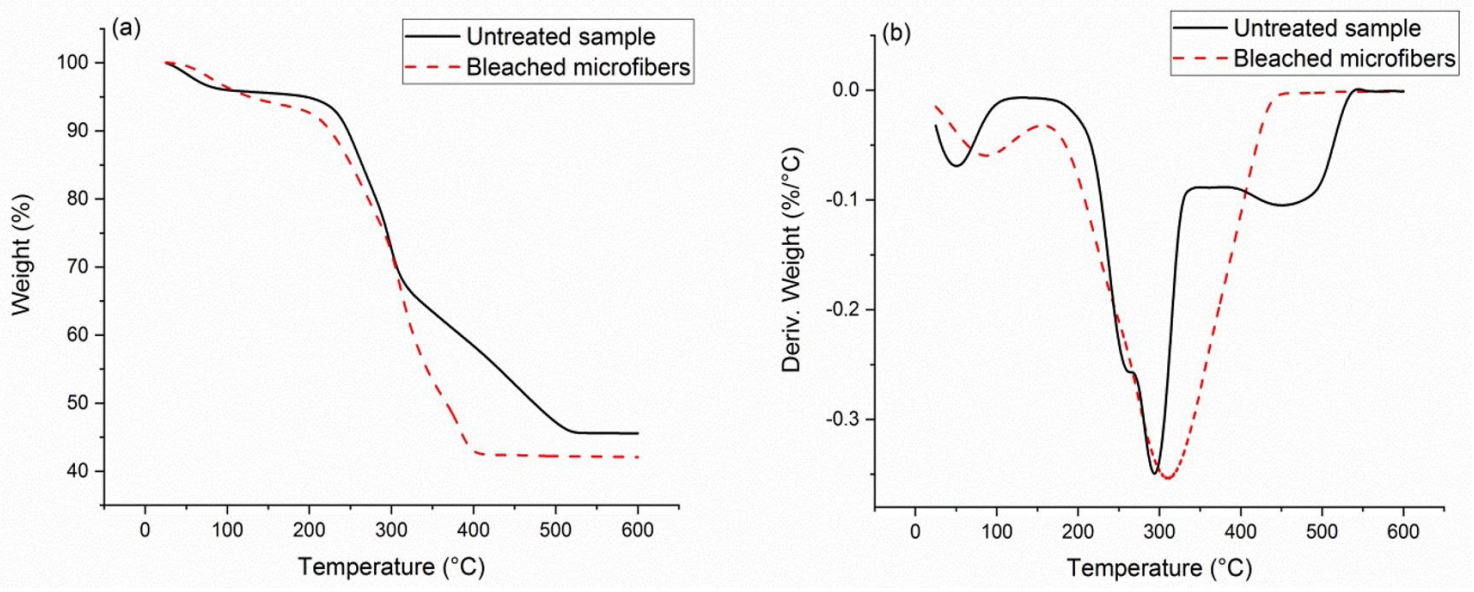

Figure 4. TGA (a) and DTG (b) curves of the untreated sample and the bleached cellulose microfibers.

Table 4. DTGmax and char yields of cellulose microfibers from different sources.

\begin{tabular}{lccc}
\hline \multicolumn{1}{c}{ Samples } & $\mathbf{T}_{\text {max }}\left({ }^{\circ} \mathbf{C}\right)$ & Char (\%) & Reference \\
\hline Date seeds cellulose microfibers & 300 & 11 & Nabili et al..$^{[48]}$ \\
Bamboo cellulose microfibers & 328 & 13 & ${\text { Chen et al. }{ }^{[49]}}^{[50]}$ \\
Rice hulls microcrystalline cellulose & 283 & 23 & Adel et al. $^{[50]}$ \\
bean hulls microcrystalline cellulose & 281 & 25 & Adel et al. $^{\left[{ }^{20]}\right.}$ \\
Onion skin cellulose microfibers & 333 & 26 & Reddy and Rhim $^{[51]}$ \\
Retama Raetam cellulose microfibers & 311 & 42 & This work \\
Cotton silver microcrystalline cellulose & 340 & 57 & Das et al..$^{[52]}$ \\
Jute microcrystalline cellulose & 280 & 61 & Das et al..$^{[52]}$ \\
\hline
\end{tabular}

$311{ }^{\circ} \mathrm{C}$ for the raw and bleached samples, respectively. A shoulder can be clearly observed at $261{ }^{\circ} \mathrm{C}$ on the left side of the main peak of the raw sample DTG curve, which was due to initial decomposition of hemicellulose and non-cellulosic components ${ }^{[47]}$, while the broadening at $245^{\circ} \mathrm{C}$ on the microfibers DTG curve, could be an indicator of a broad distribution of molecular mass from cellulose or a residual content of hemicellulose which withstood the extracting procedures ${ }^{[26]}$. Finally, the formation of a charred residue took place ( $46 \%$ for raw sample and $42 \%$ for cellulose microfibers). The higher charred residue of the raw sample is due to the fact that the non-cellulosic components could induce higher char formation ${ }^{[38]}$. However, R. Raetam cellulose microfibers presented relatively high char yield when compared to literature (Table 4), indicating higher non-volatile carbonaceous material generated on pyrolysis ${ }^{[53]}$ and could indicate also a good thermal stability of the extracted cellulose microfibers ${ }^{[20,54]}$

\section{Conclusion}

The main goal of this work was to investigate the viability of Retama Raetam as a novel, renewable and low-cost source of cellulose microfibers. The successful isolation of cellulose microfibers was achieved with a yield of $52.1 \%$ by stepwise chemical treatments. The FTIR results revealed that the chemical treatments removed most of lignin and hemicellulose from the sample. The extracted cellulose microfibers were highly crystalline native cellulose I, with a crystallinity of $77.8 \%$ and a crystallite size of $3.62 \mathrm{hm}$. The diameter of the micro-sized fibers was about 6-7 $\mu \mathrm{m}$. TGA/DTG curves show a maximum decomposition peak at $31{ }^{\circ} \mathrm{C}$ and a high char yield. These findings proved that $\mathrm{R}$. Raetam is a candidate renewable source for the production of cellulose microfibers and should stimulate further research on the use of these fibers for various applications such as cellulose nanocrystals preparation, reinforcement agent in green biocomposites and bio-fillers for polymer matrices.

\section{References}

1. Baskaran, P., Kathiresan, M., Senthamaraikannan, P., \& Saravanakumar, S. (2018). Characterization of new natural cellulosic fiber from the bark of dichrostachys cinerea. Journal of Natural Fibers, 15(1), 62-68. http://dx.doi.org/10.1080/15 440478.2017.1304314.

2. Mohammed, L., Ansari, M. N. M., Pua, G., Jawaid, M., \& Islam, M. S. (2015). A review on natural fiber reinforced polymer composite and its applications. International Journal of Polymer Science, 15. http://dx.doi.org/10.1155/2015/243947.

3. Sheltami, R. M., Abdullah, I., Ahmad, I., Dufresne, A., \& Kargarzadeh, H. (2012). Extraction of cellulose nanocrystals from mengkuang leaves (Pandanus tectorius). Carbohydrate Polymers, 88(2), 772-779. http://dx.doi.org/10.1016/j. carbpol.2012.01.062.

4. Zain, N. F. M., Yusop, S. M., \& Ahmad, I. (2014). Preparation and characterization of cellulose and nanocellulose from pomelo 
(Citrus grandis) albedo. Journal of Nutrition \& Food Sciences, 5(1), 334. http://dx.doi.org/10.4172/2155-9600.1000334.

5. Zhao, L., Pang, Q., Xie, J., Pei, J., Wang, F., \& Fan, S. (2013). Enzymatic properties of Thermoanaerobacterium thermosaccharolyticum $\beta$-glucosidase fused to Clostridium cellulovorans cellulose binding domain and its application in hydrolysis of microcrystalline cellulose. BMC Biotechnology, 13(1), 101. http://dx.doi.org/10.1186/1472-6750-13-101. PMid:24228818.

6. Braconnot, H. (1819). Sur la conversion du corps ligneux en gomme, en sucre, et en un acide d'une nature particulière, par le moyen de l'acide sulfurique; conversion de la même substance ligneuse en ulmine par la potasse. Annales de Chimie et de Physique, 12, 172-195.

7. Payen, A. (1838). Mémoire sur la composition du tissu propre des plantes et du ligneux. The C++Report, 7, 1052-1056.

8. Naduparambath, S., Jinitha, T., Shaniba, V., Sreejith, M., Balan, A. K., \& Purushothaman, E. (2018). Isolation and characterisation of cellulose nanocrystals from sago seed shells. Carbohydrate Polymers, 180, 13-20. http://dx.doi. org/10.1016/j.carbpol.2017.09.088. PMid:29103489.

9. Vestena, M., Gross, I. P., Muller, C. M. O., \& Pires, A. T. N. (2016). Isolation of whiskers from natural sources and their dispersed in a non-aqueous medium. Polímeros, 26(4), 327335. http://dx.doi.org/10.1590/0104-1428.2367.

10. Penjumras, P., Rahman, R. B. A., Talib, R. A., \& Abdan, K. (2014). Extraction and characterization of cellulose from durian rind. Agriculture and Agricultural Science Procedia, 2, 237-243. http://dx.doi.org/10.1016/j.aaspro.2014.11.034.

11. Li, M., Wang, L., Li, D., Cheng, Y.-L., \& Adhikari, B. (2014). Preparation and characterization of cellulose nanofibers from de-pectinated sugar beet pulp. Carbohydrate Polymers, 102, 136-143. http://dx.doi.org/10.1016/j.carbpol.2013.11.021. PMid:24507265.

12. Reddy, N., \& Yang, Y. (2009). Extraction and characterization of natural cellulose fibers from common milkweed stems. Polymer Engineering and Science, 49(11), 2212-2217. http:// dx.doi.org/10.1002/pen.21469.

13. Reddy, N., \& Yang, Y. (2009). Properties of natural cellulose fibers from hop stems. Carbohydrate Polymers, 77(4), 898902. http://dx.doi.org/10.1016/j.carbpol.2009.03.013.

14. Johar, N., Ahmad, I., \& Dufresne, A. (2012). Extraction, preparation and characterization of cellulose fibres and nanocrystals from rice husk. Industrial Crops and Products, 37(1), 93-99. http://dx.doi.org/10.1016/j.indcrop.2011.12.016.

15. Indran, S., Edwin Raj, R., \& Sreenivasan, V. S.. (2014). Characterization of new natural cellulosic fiber from Cissus quadrangularis root. Carbohydrate Polymers, 110, 423-429. http://dx.doi.org/10.1016/j.carbpol.2014.04.051. PMid:24906775.

16. Kacem, I., Majdoub, H., \& Roudesli, S. (2008). Physicochemical properties of pectin from retama raetam obtained using sequential extraction. Journal of Applied Sciences, 8(9), 1713-1719. http:// dx.doi.org/10.3923/jas.2008.1713.1719.

17. Bokhari-Taieb Brahimi, H., Faugeron, C., Hachem, K., KaidHarche, M., \& Gloaguen, V. (2015). Investigation of parietal polysaccharides from Retama raetam roots. African Journal of Biotechnology, 14(29), 2327-2334. http://dx.doi.org/10.5897/ AJB2015.14754.

18. Mechergui, K., Mahmoudi, H., Khouja, M. L., \& Jaouadi, W. (2017). Factors influencing seed germination of the pastoral plant Retama raetam subsp. bovei (Fabaceae): interactive effects of fruit morphology, salinity, and osmotic stress. Biologija, 63(2), 134-151. http://dx.doi.org/10.6001/biologija.v63i2.3525.

19. Segal, L., Creely, J., Martin, A. Jr, \& Conrad, C. (1959). An empirical method for estimating the degree of crystallinity of native cellulose using the X-ray diffractometer.
Textile Research Journal, 29(10), 786-794. http://dx.doi. org/10.1177/004051755902901003.

20. Kale, R. D., Bansal, P. S., \& Gorade, V. G. (2018). Extraction of microcrystalline cellulose from cotton sliver and its comparison with commercial microcrystalline cellulose. Journal of Polymers and the Environment, 26(1), 355-364. http://dx.doi.org/10.1007/s10924-017-0936-2.

21. Sun, X.-F., Sun, R.-C., Su, Y., \& Sun, J.-X. (2004). Comparative study of crude and purified cellulose from wheat straw. Journal of Agricultural and Food Chemistry, 52(4), 839-847. http:// dx.doi.org/10.1021/jf0349230. PMid:14969539.

22. Uma Maheswari, C., Obi Reddy, K., Muzenda, E., Guduri, B. R., \& Varada Rajulu, A. (2012). Extraction and characterization of cellulose microfibrils from agricultural residue - Cocos nucifera L. Biomass and Bioenergy, 46, 555-563. http://dx.doi. org/10.1016/j.biombioe.2012.06.039.

23. Jonjankiat, S., Wittaya, T., \& Sridach, W. (2011). Improvement of poly (vinyl alcohol) adhesives with cellulose microfibre from sugarcane bagasse. Iranian Polymer Journal, 20(4), 305-317.

24. Reddy, K. O., Zhang, J., Zhang, J., \& Rajulu, A. V. (2014). Preparation and properties of self-reinforced cellulose composite films from Agave microfibrils using an ionic liquid. Carbohydrate Polymers, 114, 537-545. http://dx.doi. org/10.1016/j.carbpol.2014.08.054. PMid:25263924.

25. Alemdar, A., \& Sain, M. (2008). Isolation and characterization of nanofibers from agricultural residues-Wheat straw and soy hulls. Bioresource Technology, 99(6), 1664-1671. http://dx.doi. org/10.1016/j.biortech.2007.04.029. PMid:17566731.

26. Morán, J. I., Alvarez, V. A., Cyras, V. P., \& Vázquez, A. (2008). Extraction of cellulose and preparation of nanocellulose from sisal fibers. Cellulose, 15(1), 149-159. http://dx.doi.org/10.1007/ s10570-007-9145-9.

27. Sonia, A., \& Priya Dasan, K. (2013). Chemical, morphology and thermal evaluation of cellulose microfibers obtained from Hibiscus sabdariffa. Carbohydrate Polymers, 92(1), 668-674. http://dx.doi.org/10.1016/j.carbpol.2012.09.015. PMid:23218352.

28. Reddy, K. O., Maheswari, C. U., Dhlamini, M. S., \& Kommula, V. P. (2016). Exploration on the characteristics of cellulose microfibers from Palmyra palm fruits. International Journal of Polymer Analysis and Characterization, 21(4), 286-295. http://dx.doi.org/10.1080/1023666X.2016.1147799.

29. Reddy, K. O., Maheswari, C. U., Dhlamini, M. S., Mothudi, B. M., Kommula, V. P., Zhang, J., Zhang, J., \& Rajulu, A. V. (2018). Extraction and characterization of cellulose single fibers from native african napier grass. Carbohydrate Polymers, 188, 85-91. http://dx.doi.org/10.1016/j.carbpol.2018.01.110. PMid:29525176.

30. Fan, M., Dai, D., \& Huang, B. (2012). Fourier transform infrared spectroscopy for natural fibres. In S. M. Salih (Ed.), Fourier transform-materials analysis (pp. 45-68). Rijeka: InTech. http://dx.doi.org/10.5772/35482.

31. Maryana, R., Ma'rifatun, D., Wheni, A., Satriyo, K., \& Rizal, W. A. (2014). Alkaline pretreatment on sugarcane bagasse for bioethanol production. Energy Procedia, 47, 250-254. http:// dx.doi.org/10.1016/j.egypro.2014.01.221.

32. Oh, S. Y., Yoo, D. I., Shin, Y., Kim, H. C., Kim, H. Y., Chung, Y. S., Park, W. H., \& Youk, J. H. (2005). Crystalline structure analysis of cellulose treated with sodium hydroxide and carbon dioxide by means of X-ray diffraction and FTIR spectroscopy. Carbohydrate Research, 340(15), 2376-2391. http://dx.doi. org/10.1016/j.carres.2005.08.007. PMid:16153620.

33. Sun, J. X., Sun, X. F., Zhao, H., \& Sun, R. C. (2004). Isolation and characterization of cellulose from sugarcane bagasse. Polymer Degradation \& Stability, 84(2), 331-339. http://dx.doi. org/10.1016/j.polymdegradstab.2004.02.008. 
34. Gao, X., Chen, K.-L., Zhang, H., Peng, L.-C., \& Liu, Q.-X. (2014). Isolation and characterization of cellulose obtained from bagasse pith by oxygen-containing agents. BioResources, 9(3), 4094-4107. http://dx.doi.org/10.15376/biores.9.3.4094-4107.

35. Sain, M., \& Panthapulakkal, S. (2006). Bioprocess preparation of wheat straw fibers and their characterization. Industrial Crops and Products, 23(1), 1-8. http://dx.doi.org/10.1016/j. indcrop.2005.01.006

36. Kondo, T., \& Sawatari, C. (1996). A Fourier transform infra-red spectroscopic analysis of the character of hydrogen bonds in amorphous cellulose. Polymer, 37(3), 393-399. http://dx.doi. org/10.1016/0032-3861(96)82908-9.

37. Kondo, T. (1997). The assignment of IR absorption bands due to free hydroxyl groups in cellulose. Cellulose, 4(4), 281-292. http://dx.doi.org/10.1023/A:1018448109214.

38. Flauzino, W. P., No., Silvério, H. A., Dantas, N. O., \& Pasquini, D. (2013). Extraction and characterization of cellulose nanocrystals from agro-industrial residue-soy hulls. Industrial Crops and Products, 42, 480-488. http://dx.doi.org/10.1016/j. indcrop.2012.06.041.

39. French, A. D. (2014). Idealized powder diffraction patterns for cellulose polymorphs. Cellulose, 21(2), 885-896. http:// dx.doi.org/10.1007/s10570-013-0030-4.

40. Park, S., Baker, J. O., Himmel, M. E., Parilla, P. A., \& Johnson, D. K. (2010). Cellulose crystallinity index: measurement techniques and their impact on interpreting cellulase performance. Biotechnology for Biofuels, 3(1), 10. http:// dx.doi.org/10.1186/1754-6834-3-10. PMid:20497524.

41. Wang, Y., Zhao, Y., \& Deng, Y. (2008). Effect of enzymatic treatment on cotton fiber dissolution in $\mathrm{NaOH} /$ urea solution at cold temperature. Carbohydrate Polymers, 72(1), 178-184. http://dx.doi.org/10.1016/j.carbpol.2007.08.003.

42. Rhim, J.-W., Reddy, J. P., \& Luo, X. (2015). Isolation of cellulose nanocrystals from onion skin and their utilization for the preparation of agar-based bio-nanocomposites films. Cellulose, 22(1), 407-420. http://dx.doi.org/10.1007/s10570014-0517-7.

43. Abe, K., \& Yano, H. (2009). Comparison of the characteristics of cellulose microfibril aggregates of wood, rice straw and potato tuber. Cellulose, 16(6), 1017-1023. http://dx.doi.org/10.1007/ s10570-009-9334-9.

44. Chatterjee, A., Kiran Kumar, G., Dharma Sagar, B., Sravanti, K., Ramakrishna, K., \& Rajesh, C. (2018). Pure and copper doped cellulose microfibers-a case study. Materials Research Express, 5(10), 105302. http://dx.doi.org/10.1088/2053-1591/ aad9d4.

45. Puttaswamy, M., Srinikethan, G., \& Shetty, K. V. (2017). Biocomposite composed of PVA reinforced with cellulose microfibers isolated from biofuel industrial dissipate: Jatropha Curcus L. seed shell. Journal of Environmental Chemical
Engineering, 5(2), 1990-1997. http://dx.doi.org/10.1016/j. jece.2017.04.004.

46. C S, J. C., George, N., \& Narayanankutty, S. K. (2016). Isolation and characterization of cellulose nanofibrils from arecanut husk fibre. Carbohydrate Polymers, 142, 158-166. http:// dx.doi.org/10.1016/j.carbpol.2016.01.015. PMid:26917386.

47. Kasiri, N., \& Fathi, M. (2018). Production of cellulose nanocrystals from pistachio shells and their application for stabilizing Pickering emulsions. International Journal of Biological Macromolecules, 106, 1023-1031. http://dx.doi. org/10.1016/j.ijbiomac.2017.08.112. PMid:28842201.

48. Nabili, A., Fattoum, A., Brochier-Salon, M.-C., Bras, J., \& Elaloui, E. (2017). Synthesis of cellulose triacetate-I from microfibrillated date seeds cellulose (Phoenix dactylifera L.). Iranian Polymer Journal, 26(2), 137-147. http://dx.doi. org/10.1007/s13726-017-0505-5.

49. Chen, W., Yu, H., Liu, Y., Hai, Y., Zhang, M., \& Chen, P. (2011). Isolation and characterization of cellulose nanofibers from four plant cellulose fibers using a chemical-ultrasonic process. Cellulose, 18(2), 433-442. http://dx.doi.org/10.1007/ s10570-011-9497-z.

50. Adel, A. M., Abd El-Wahab, Z. H., Ibrahim, A. A., \& AlShemy, M. T. (2011). Characterization of microcrystalline cellulose prepared from lignocellulosic materials. Part II: physicochemical properties. Carbohydrate Polymers, 83(2), 676-687. http://dx.doi.org/10.1016/j.carbpol.2010.08.039.

51. Reddy, J. P., \& Rhim, J.-W. (2018). Extraction and characterization of cellulose microfibers from agricultural wastes of onion and garlic. Journal of Natural Fibers, 15(4), 465-473. http://dx.doi. org/10.1080/15440478.2014.945227.

52. Das, K., Ray, D., Bandyopadhyay, N. R., \& Sengupta, S. (2010). Study of the properties of microcrystalline cellulose particles from different renewable resources by XRD, FTIR, nanoindentation, TGA and SEM. Journal of Polymers and the Environment, 18(3), 355-363. http://dx.doi.org/10.1007/ s10924-010-0167-2.

53. Azubuike, C. P., \& Okhamafe, A. O. (2012). Physicochemical, spectroscopic and thermal properties of microcrystalline cellulose derived from corn cobs. International Journal of Recycling of Organic Waste in Agriculture, 1(1), 9. http:// dx.doi.org/10.1186/2251-7715-1-9.

54. Das, K., Ray, D., Bandyopadhyay, N. R., Ghosh, T., Mohanty, A. K., \& Misra, M. (2009). A study of the mechanical, thermal and morphological properties of microcrystalline cellulose particles prepared from cotton slivers using different acid concentrations. Cellulose, 16(5), 783-793. http://dx.doi. org/10.1007/s10570-009-9280-6.

Received: Aug. 03, 2018

Revised: Sept. 21, 2018

Accepted: Oct. 23, 2018 